\title{
DOSSIÊ: TRANSLATION IN TEACHING AND LEARNING FOREIGN LANGUAGES
}

\author{
Maria Cristina Reckziegel Guedes EVANGELISTA ${ }^{2}$ \\ Paula Tavares PINTO ${ }^{3}$ \\ Odair Luiz NADIN ${ }^{4}$
}

\section{PRESENTATION}

The journal EntreLínguas aims at "Publishing articles, reports, critical reviews and interviews by national and international researchers about language teaching and learning of modern foreign languages (MFL), with the aim of promoting a debate on the theoretical and methodological processes of teaching of MFL".

In this context, we present a special issue of EntreLínguas (V.3, n.2, 2017, 2nd semester), on the theme "Translation in teaching and learning foreign languages". This subject is still controversial and continues to be a taboo for many foreign language teachers and researchers, although studies on it have never been disrupted, as shown, for example, by the compilation of bibliographical references by Ridd (2009) and an extensive study on foreign language teaching in the European Union prepared by Pym; Malmkjær and Gutiérrez-Colón Plana (2013).

Among the works already published, there is a tendency to present first a retrospective on the methods and approaches of foreign language teaching, followed by the justification for the use of the translation as shown in the following works, presented in increasing chronological order: Terra (2010); Tecchio; Bittencourt (2011); Briks (2012), Liberatti (2012); Souza Corrêa (2014), among others. The articles of this volume focus mainly on the discussion at a later stage to this justification phase,

${ }^{1}$ Translation to English Paula Tavares Pinto and Maria Cristina Reckziegel Guedes Evangelista

${ }^{2}$ São Paulo State University (Unesp), School of Humanities and Sciences, Araraquara - SP - Brasil. Assistant Professor of the Department of Modern Languages. E-mail: macrisevangelista@fclar.unesp.br.

${ }^{3}$ São Paulo State University (Unesp), Institute of Biosciences, Humanities and Exact Sciences, São José do Rio Preto - SP - Brasil. Assistant Professor of the Department of Modern Languages. E-mail: paula@ibilce.unesp.br.

${ }^{4}$ São Paulo State University (Unesp), School of Humanities and Sciences, Araraquara - SP - Brasil. Assistant Professor of the Department of Modern Languages. E-mail: odairnadin@ fclar.unesp.br. 
pointing out concrete reasons for the use of translation and some ways of inserting it into teaching and learning contexts.

Valdecy Oliveira Pontes and Livya Lea Oliveira Pereira, in the article Functional translation and linguistic variation: the use of didactic sequence in language teaching, report on the elaboration of a didactic sequence in which there are translated pieces of theatre plays from different Hispanic countries, focusing on the forms of treatment of Spanish and Portuguese.

Elisa Figueira de Souza Corrêa presents the article Pedagogic translation: experiments and exercises to do in class and postulates that the translation ability can be placed with the four traditional skills, reading and writing, listening and speaking and thus contribute to the student's linguistic awareness.

Sinara de Oliveira Branco and Luciana Soares dos Santos elaborated the article The use of intersemiotic and interlingual translation activities in an EFL classroom, in which they try to evidence the effectiveness of the use of translation as an English language teaching tool by taking on the basis of the categories of translation proposed by Jakobson (1958/2000) and following a methodology of qualitative nature and action research.

Aline Cantarotti presents Data-driven learning, translation and executive secretariat: a self study approach proposal for English learners. Her research approaches the work methodology of corpus linguistics to the scope of foreign language learning, leading the learner to discover for himself the lexical-grammatical features of the language he or she studies.

Viviane Cristina Poletto Lugli, author of the article The expression of modal verbs in the translation of decision genre: contributions to foreign language teaching, proposes the comparison between excerpts of parts of this genre in Portuguese, Spanish and English, joining the study of the foreign language and of the textual genres.

Paolo E. Balboni, in Translation in language learning: a 'what for' approach, seeks to evaluate how translation can bring benefits to the different skills related to linguistic, extralinguistic, socio-pragmatic and intercultural skills of foreign language learners.

Bruna Di Sabato and Bronwen Hughes in the article Translation and foreign language teaching, a theoretical and practical point of view: the Italian scenario, discuss the role of translation in curricula of Italian universities and point out some translation activities that can be developed by language learners. 
Joselma Maria Noal; Artur Emilio Alarcon Vaz and Daniele Corbetta Pilleti bring discussions on Literary translation in Language Teaching. Her research is based on the learners' translation of short stories by the Argentinean writer Juana Manuela Gorriti, and analyzes translation difficulties related to the grammatical, lexical and stylistic fields, showing that this work can also bring learners closer to cultural issues.

Krisztina Zimanyi presents the article Gateways into teaching translation in the language classroom: A proposal for audiovisual translation of Coraline in EFL / ESOL. The activities proposed by the author include the intralingual, interlingual and intersemiotic translation (Jakobson, 1959/2000) and seek to motivate learners, promoting their autonomy.

Glauber Lima Moreira presents the interview with Dr. DeCesaris of the Universitat Pompeu Fabra (UPF), entitled The role of translation in the teaching of modern foreign languages. The interviewee understands the translation mainly as a didactic tool, which allows the comparison between languages, promoting awareness of linguistic issues.

\section{REFERENCES}

BRIKS, F. J. P. Tradução: Ferramenta eficaz no ensino-aprendizagem de línguas estrangeiras para o aluno do ensino superior. In: Belas Infiéis, v. 1, n. 1, p. 153-167, 2012.

JAKOBSON, R. On linguistic aspects of translation. In: VENUTI, L. The Translation Studies Reader. London/New York: Routledge, 113-118, 1959/2000.

LIBERATTI, E. A tradução na sala de aula de LE: (des)construindo conceitos. In: Entrepalavras, Fortaleza, ano 2, v. 2, n. 1, p. 175-187, 2012.

PYM, A.; GUTIÉRREZ-COLÓN PLANA, M. d. M.; MALMKJAER, K. Translation and language learning: the role of translation in the teaching of languages in the European Union. A Study. Directorate-General for Translation - European Commission. 15 July 2013.

RIDD, M. Bibliografia de referência sobre tradução no ensino e aprendizagem de línguas. In: Horizontes de Linguística Aplicada, v. 8, n. 2, p. 255-296, 2009.

SOUZA CORRÊA, E. F. de. A língua materna e a tradução no ensinoaprendizagem de língua não-materna: uma historiografia crítica. Tese de doutorado. PUC, Rio de Janeiro, 2014. 
TECCHIO, I.; BITTENCOURT, M. J. G. A tradução no ensino-aprendizagem de línguas estrangeiras. In: Revista Magistro, v. 2, n. 1, p. 152-165, 2011. Disponível em:

TERRA, M. R. Tradução \& aprendizado de língua estrangeira: o ponto de vista do aluno. Trab. Ling. Aplic., Campinas, v. 49, n.1, p. 69-85, jan./jun. 2010.

\section{How to cite this text:}

EVANGELISTA, Maria Cristina Reckziegel Guedes.; PINTO, Paula Tavares.; NADIN, Odair Luiz. Presentation Dossiê: Translation in teaching and learning foreign languages. Rev. EntreLínguas, Araraquara, v.3, n.2, p. 145-148, jul./dez. 2017. Disponível em: <https://doi.org/10.29051/rel.v3.n2.2017.10797>. E-ISSN: 2447-3529. 